\title{
Inspection of infant motor development: importance of the insertion of a physical therapist in childcare
}

\section{Vigilância do desenvolvimento}

motor de bebês: importância

da inserção do fisioterapeuta

na puericultura

Karine Diehl Pinheiro-Rubim (1) ${ }^{1 *}$

Ângela Kemel Zanella (i) ${ }^{2}$

Eloá Maria dos Santos Chiquetti ${ }^{1}{ }^{1}$

${ }^{1}$ Universidade Federal do Pampa (UNIPAMPA), Uruguaiana RS, Brazil

2 Universidade Federal de Santa Maria (UFSM), Santa Maria, RS, Brazil

Date of first submission: December 17, 2020

Last received: March 3, 2021

Accepted: May 10, 2021

Associate editor: Talita Gianello Gnoato Zotz

*Correspondence: karinediehl@gmail.com

\begin{abstract}
Introduction: The Childcare Program aims at the health promotion, prevention and early diagnosis of diseases and recovery from diseases in childhood through programmed monitoring of the child's growth and development. A physical therapist can contribute to the early identification of neuropsychomotor developmental disorders. Objective: To characterize the motor development (DM) of infants during childcare consultations and to discuss the importance of a professional physical therapist in primary health care teams. Methods: The sample comprised 91 infants aged 0-6 months attended in childcare consultations. Infants with musculoskeletal disorders, neuropathology, and those who cried bitterly, thereby preventing the evaluation were excluded. DM was evaluated using the Alberta Infant Motor Scale. Results: Of the infants aged 0-3 months, $11.76 \%$ had atypical DM, $23.62 \%$ were at risk for motor delay, and $64.07 \%$ had typical DM. Among the infants aged 4-6 months (25.3\%), less than half of the children (39.13\%) had typical DM. Among the infants aged 4-6 months who did not have typical DM, $40 \%$ belonged to the group of premature infants. Conclusion: As the child grows, the motor experiences should be more challenging for DM to constantly evolve. The insertion of a physical therapist in childcare, together with the Family Health Strategy team, can expand care and guarantee the assessment, monitoring, and promotion of early stimulation of childhood DM, in addition to the recognition of its importance in primary care.
\end{abstract}

Keywords: Child care. Child development. Physical therapy. 


\section{Resumo}

Introdução: O Programa de Puericultura tem por intuito a promoção, prevenção, diagnóstico precoce e recuperação dos agravos na infância através do acompanhamento programado do crescimento e desenvolvimento da criança. O profissional fisioterapeuta pode contribuir na identificação precoce de desordens do desenvolvimento neuropsicomotor. Objetivo: Caracterizar o desenvolvimento motor (DM) dos bebês atendidos durante as consultas de puericultura e discutir a importância do profissional fisioterapeuta na equipe de atenção básica à saúde.

Métodos: $A$ amostra foi composta por 91 bebês de 0 a 6 meses de idade, atendidos em consultas de puericultura. Foram excluídos os bebês com afecções osteomioarticulares, neuropatologia e choro intenso que impedisse a avaliação. Foi realizada avaliação do DM com a Escala Motora Infantil de Alberta. Resultados: Dos bebês de 0 a 3 meses de idade, 11,76\% estavam com DM atípico, $23,62 \%$ com risco para o atraso motor, e 64,07\% com DM típico. Já as crianças de 4 a 6 meses (25,3\%), menos da metade das crianças $(39,13 \%)$ atingiram o DM típico. Desses que não atingiram o DM típico no segundo trimestre de vida, $40 \%$ pertencem ao grupo de prematuros. Conclusão: À medida que a criança cresce, suas vivências motoras devem ser mais desafiadoras para que o DM mantenha evolução constante. A inserção do fisioterapeuta na puericultura, junto à equipe de Estratégia de Saúde da família, pode ampliar o cuidado e garantir a avaliação, acompanhamento e promoção da estimulação precoce do DM infantil, além do reconhecimento de sua importância na atenção básica.

Palavras-chave: Puericultura. Desenvolvimento infantil. Fisioterapia.

\section{Introduction}

The Ministry of Health (MS) instituted the National Policy for Integral Child Health Care, which aims at health promotion, prevention and early diagnosis of diseases, and recovery from diseases in childhood in conjunction with the scheduled monitoring of growth and development. ${ }^{1}$ One of the resources used to monitor this is the Childcare Program, which comprises a set of techniques used to monitor and evaluate the child's physical and mental development from the gestational period until the age of 4 or 5 years. ${ }^{2}$ The recommendation of the MS is at least seven routine consultations during the infant's first year of life. ${ }^{3}$
Childcare does not focus on monitoring and controlling growth. ${ }^{2}$ Observing child development, especially motor development (DM), is of utmost importance. ${ }^{4} \mathrm{DM}$ is sequential and continuous, evolving as maturation occurs. The central nervous system and the stimuli that are received in the environmental context affect DM; therefore, DM is influenced by multifactorial characteristics. ${ }^{4,5}$ Deviations from DM can be the first sign of motor disorder or delay and can be detected both in full-term infants and preterm infants during the first year of life. ${ }^{6,7}$ During this period, DM is fast and extensive because of great neural plasticity. Therefore, early diagnosis is very important for interventions to start as soon as possible.

During the early stage of development, the infant uses information provided by exploring the environment through movement. These explorations can strengthen and inhibit their development. Research highlights the influence and importance of several factors in development, including the mother's age, maternal practices through daily handling, environmental opportunities, and the socioeconomic status and educational level of the parents. ${ }^{7,8}$

For comprehensive assistance to the care and health of children in primary care $(A B)$, it is necessary to include a physical therapist in the interdisciplinary team to contribute to childcare by early identification of any kinetic functional changes and delay in the child's DM. ${ }^{9,10}$ This delay can have a negative impact on activities of daily living, leading to poor performance in self-care skills, as well as poor manual coordination with consequent difficulty in writing, causing loss of schooling, often requiring therapeutic intervention. ${ }^{7}$

The presence of a physical therapist in the $A B$ team helps to assess child development as well to understand the profile of this age group, since assessments performed by the physical therapist helps in the early identification of motor changes. In addition, the physical therapist can formulate a daily care plan for health promotion and the prevention of injuries resulting from these delays, especially with home guidelines, finding strategies with families that provide an environment rich in stimuli for optimal development. ${ }^{4,10,11}$

Currently, physical therapists are not part of the primary Family Health Strategy (FHS) team. On the other hand, a physical therapist can be a part of the Family Health Support Center (NASF) team, which has enhanced their role in primary care and made physical therapy services more accessible. In the current model, the NASF 
supports at least five family health teams, ${ }^{11,12}$ making the presence of a physical therapist in routine childcare consultations unfeasible. It is known that the insertion of this professional in the FHS team can promote continuous, resolutive, and integral care to this population. ${ }^{10}$

This study aimed to characterize, through the actions of a resident physical therapist inserted in the childcare team, the DM of infants attended to during childcare consultations at the FHS and Child Care Center in the city of Uruguaiana, RS, Brazil, and to discuss the importance of a physical therapist in the primary health care team.

\section{Methods}

\section{Study design}

This was a cross-sectional observational study of a quantitative and descriptive nature, with data collected during childcare consultations at the FHS and Child Care Center in the municipality of Uruguaiana, RS, with authorization from the FHS and on obtaining consent from the parents and/or guardians. This research was conducted from March 2019 to September 2019, when a resident physical therapist was inserted into this health service. The Ethics and Research Committee on Human Beings at the Universidade Federal do Pampa approved this project, under opinion No. 2,351,501.

\section{Sample}

The sample comprised 91 babies aged 0-6 months, who were attended to during the childcare consultations at the FHS and Child Care Center in the municipality of Uruguaiana, RS, as recommended by the MS. User data were intentionally recruited according to the demands of the health units. Each infant was evaluated once. Infants were included based on the following criteria: infants aged (chronological age and corrected age for premature infants) 0-6 months, Brazilians, and those who have not participated in intervention programs. Infants with musculoskeletal disorders or any other neuropathology and those who cried bitterly, thereby preventing the assessment were excluded from the study.

\section{Assessment tools}

Neonatal and gestational data such as weight, length, and head circumference at birth, gestational age, and the mother's age were recorded in the infant's vaccine booklet and the user's medical records.

The DM evaluation was carried out using the Alberta Infant Motor Scale (AIMS), developed to measure the gross motor maturation of children from birth to the age of independent walking or 18 months of age, validated for Brazilian children. ${ }^{13}$ This is an observational test based on the repertoire of spontaneous movement demonstrated by the child in the prone (21 items), supine ( 9 items), sitting (12 items), and standing (16 items) postures. During the evaluation, the spontaneous movement of the infant in each posture was observed, with minimal handling by the evaluator. The study involved a single evaluator who received theoretical and practical training. ${ }^{14}$ The total score obtained by the infant was converted into the DM percentile, with typical DM being classified as $>25$ on the percentile curve. There is a risk of motor delay when the infant obtains a score between 25 and 5 on the percentile curve and of atypical motor development when the score is below $5 .^{13}$ The materials needed for the evaluation were the AIMS manual, a rattle, and a sounding rubber toy. In addition, the infants were in light clothing so that their movements were not restricted. The test scores were recorded on the infant's care record.

After the evaluation and based on the results, the mothers were individually guided on practices favorable to development, such as providing challenging postures, postural exchanges with sound, visual and tactile incentives, exploring home environments, and family interaction and unfavorable practices such as the use of walkers, prolonged exposure to electronics, and excessive permanence in the same position.

\section{Statistical analysis}

To describe the socioeconomic and biological characteristics of the participants and families involved in the study, absolute and relative frequency and mean and standard deviation were used. For all data collected, descriptive analyses of biological characteristics were performed by age and descriptive analyses of DM in postures were performed by age. The values considered for the analysis of DM in children were the total score and categorization of DM. The significance level was set at $5 \%$ ( $p<0.05$ ). SPSS version 20.0, was used for data analysis. 


\section{Results}

The sample comprised 91 infants, 44 (48.35\%) boys and 47 (51.64\%) girls, with the gestational age ranging from 29 to 41 weeks, with a mean of 38.27 ( \pm 2.33 ) weeks, and $28.57 \%$ of the infants were premature. The mean birth weight was 3262.56 ( \pm 822.22) g. The characterization of the sample with the biological characteristics of the infant, the age of the mother, and the variables mentioned above are described in Table 1.

Table 1 - Measures of central tendency and variability of biological characteristics

\begin{tabular}{lc}
\hline Variable & $\mathbf{n}=\mathbf{9 1}$ \\
\hline Sex - $\mathrm{n}(\%)$ & $44(48.35)$ \\
Male & $47(51.64)$ \\
Female & \\
Classification gestational age - $\mathrm{n}(\%)$ & $2(2.19)$ \\
Extreme prematurity & $4(4.39)$ \\
Moderate prematurity & $20(21.97)$ \\
Late prematurity & $65(71.42)$ \\
Forward & $2(2.19)$ \\
Post-term & \\
Birth weight classification - $\mathrm{n}(\%)$ & 0 \\
Extreme low weight & $1(1.10)$ \\
Very low weight & $10(10.99)$ \\
Low weight & $80(87.91)$ \\
Proper weight & \\
Nutritional status - $\mathrm{n}(\%)^{\star}$ & $1(1.10)$ \\
Small for gestational age & $67(73.62)$ \\
Suitable for gestational age & $23(25.28)$ \\
Big for gestational age & $3262.56(22.22)$ \\
Birth weight (g) - mean (SD) & $48.20(2.80)$ \\
Length at birth (cm) - mean (SD) & $33.78(2.05)$ \\
Head circumference (cm) - mean (SD) & $38.27(2.33)$ \\
Gl (weeks) - mean (SD) & $25.69(6.69)$ \\
Mother's age (years) - mean (SD) & \\
\hline
\end{tabular}

Note: $\mathrm{Gl}=$ gestational agedade gestacional. ${ }^{*}$ Classification according to intrauterine growth.

\section{Overall engine performance}

The infants' motor performance was categorized by the total score and additional percentile in the test according to age as follows: atypical motor development
(0-5 on the percentile curve), the risk for motor delay (6-25 on the percentile curve), and typical motor performance (> 25 on the percentile curve). It can be observed in Figure 1 that most of the sample comprised infants aged $0-3$ months (74.72\%). Of these, eight infants (11.76\%) had atypical DM, 16 (23.62\%) were at risk for motor delay, and 44 (64.07\%) had typical DM. In contrast, among the infants aged 4-6 months ( $n=23$, equivalent to $25.3 \%$ ), the performance was lower than that of the youngest (0-3 months), with less than half of the infants ( $n=9 ; 39.13 \%$ ) having typical DM $\left(r^{2}=0.014\right)$. Among the infants aged 4-6 months who did not have typical DM, $40 \%$ belonged to the group of premature infants.

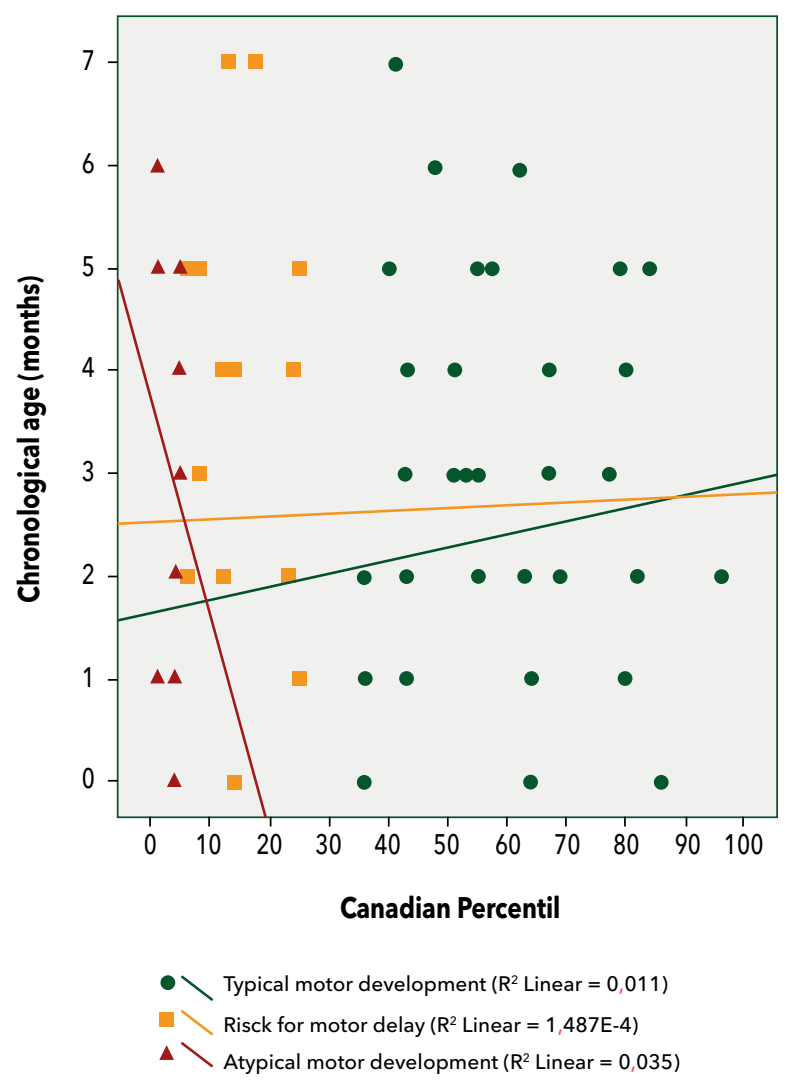

Figure 1 - Sample scatter diagram according to the categorization of children's motor development by age.

From a global perspective, the sample of the present study has an inversely proportional relationship between age and the AIMS categorization for infants with motor delay, that is, older infants had a worse percentile than younger infants, demonstrating that their motor 
acquisition was poor over time. However, the typical motor performance curve grows in proportion to the age of the children, while the younger infants had an ageappropriate percentile, the older infants managed to surpass that percentile, demonstrating an enhancement of motor acquisitions at an older age. Even though most children are within the expected range for their age, there are still inadequate percentiles for their age group.

\section{Comparisons between age groups: motor acquisitions}

When considering the items evaluated in the AIMS, the motor behavior of term and premature infants in each posture according to age can be observed in Table 2. In the prone posture, premature infants had a higher score than infants in the first month of life. Even so, the children showed a better repertoire from the fifth month when they obtained substantial gains in motor acquisitions in relation to previous ages. In the 6-month age group, there was an average difference of four items in the score of term infants compared with premature infants. However, at other ages, they achieved lower scores than premature infants.

In the sitting posture, there was a subtle difference between the groups, in which term infants had a better result in general among the different age groups. It should be considered that there were only six infants in the 6-month age group, and three of them did not have typical DM, which interferes with the final value of the mean of this score; thus, the preterm infants in the sample had a result superior to that of the term infants.

However, in the supine posture, full-term infants had better results than premature infants at certain ages. In the standing posture, it is possible to observe inferior motor behaviors, in which children have little variability and little progress across the age groups evaluated. However, full-term infants, reach the highest postures before premature infants, which can be seen in infants assessed at the age of 4 months.

Table 2 - Postural scores and total motor performance between term and preterm infants according to age in months

\begin{tabular}{|c|c|c|c|c|c|c|c|c|c|c|c|c|c|c|c|c|c|c|c|c|}
\hline \multirow{3}{*}{ 站 } & \multicolumn{4}{|c|}{ PRONE } & \multicolumn{4}{|c|}{ SITTING } & \multicolumn{4}{|c|}{ SUPINE } & \multicolumn{4}{|c|}{ STANDING } & \multicolumn{4}{|c|}{ AIMS SCORE } \\
\hline & \multicolumn{2}{|c|}{ Term } & \multicolumn{2}{|c|}{ Preterm } & \multicolumn{2}{|c|}{ Term } & \multicolumn{2}{|c|}{ Preterm } & \multicolumn{2}{|c|}{ Term } & \multicolumn{2}{|c|}{ Preterm } & \multicolumn{2}{|c|}{ Term } & \multicolumn{2}{|c|}{ Preterm } & \multicolumn{2}{|c|}{ Term } & \multicolumn{2}{|c|}{ Preterm } \\
\hline & M & SD & $M$ & SD & $M$ & SD & $M$ & SD & M & SD & $M$ & SD & $M$ & SD & $M$ & SD & $M$ & SD & M & SD \\
\hline 1 & 1.90 & 0.73 & 2.00 & 1.00 & 2.10 & 1.19 & 1.33 & 1.52 & 1.40 & 0.51 & 2.00 & 1.00 & 1.10 & 0.87 & 1.00 & 0.00 & 6.50 & 2.32 & 6.33 & 2.08 \\
\hline 2 & 2.25 & 1.21 & - & - & 2.42 & 1.08 & - & - & 2.42 & 1.37 & - & - & 1.42 & 0.51 & - & - & 7.92 & 3.87 & - & - \\
\hline 3 & 3.50 & 1.16 & 3.13 & 0.99 & 3.58 & 1.37 & 3.50 & 1.19 & 3.42 & 1.31 & 3.38 & 1.06 & 1.92 & 0.66 & 2.75 & 2.55 & 12.50 & 2.93 & 12.38 & 2.66 \\
\hline 4 & 3.83 & 0.75 & 4.00 & 2.82 & 3.83 & 1.60 & 5.00 & 1.41 & 4.00 & 0.63 & 5.50 & 2.12 & 1.83 & 0.75 & 2.50 & 0.70 & 13.50 & 2.95 & 17.00 & 7.07 \\
\hline 5 & 5.86 & 2.85 & 3.00 & - & 5.71 & 2.05 & 4.00 & - & 4.57 & 2.07 & 3.00 & - & 2.00 & 1.15 & 2.00 & - & 18.14 & 7.31 & 12.00 & - \\
\hline 6 & 10.33 & 1.15 & 6.00 & 0.00 & 7.67 & 1.15 & 8.00 & 1.41 & 7.00 & 0.00 & 7.50 & 2.12 & 3.00 & 0.00 & 3.00 & 0.00 & 28.00 & 2.00 & 24.50 & 3.53 \\
\hline Total & 3.11 & 2.44 & 2.65 & 1.57 & 2.98 & 2.14 & 2.88 & 2.21 & 2.68 & 1.94 & 2.62 & 2.29 & 1.54 & 0.81 & 1.81 & 1.65 & 10.22 & 6.81 & 9.85 & 6.54 \\
\hline
\end{tabular}

Note: AIMS = Alberta Infant Motor Scale; $\mathrm{M}=$ mean; SD = standard deviation .

Figure 2 shows the dispersion of the motor performance of term and preterm infants according to age, within the AIMS postures. Premature infants are represented by the red square and term infants are represented by the blue circle. The red dots surrounded by blue represent a term infant and a premature infant with the same score. It should be noted that there is a linear relationship between the categorization of AIMS with the prone and standing postures (Figure 2A and 2D, respectively), which have greater antigravity characteristics, thus requiring greater postural control.
In addition, there is also a relationship between age and subtests, which is an expected result, since DM is continuous; therefore, the acquisition of motor skills increases with advancing age. Figure 2A demonstrates the motor performance of term and preterm infants in the prone position, with term infants achieving higher scores at 6 months of age. Regarding the sitting posture, preterm infants performed better than full-term infants in the initial of life; however, infants assessed at the age of 5 and 6 months had a lower motor repertoire when compared with term infants (Figure 2B). 

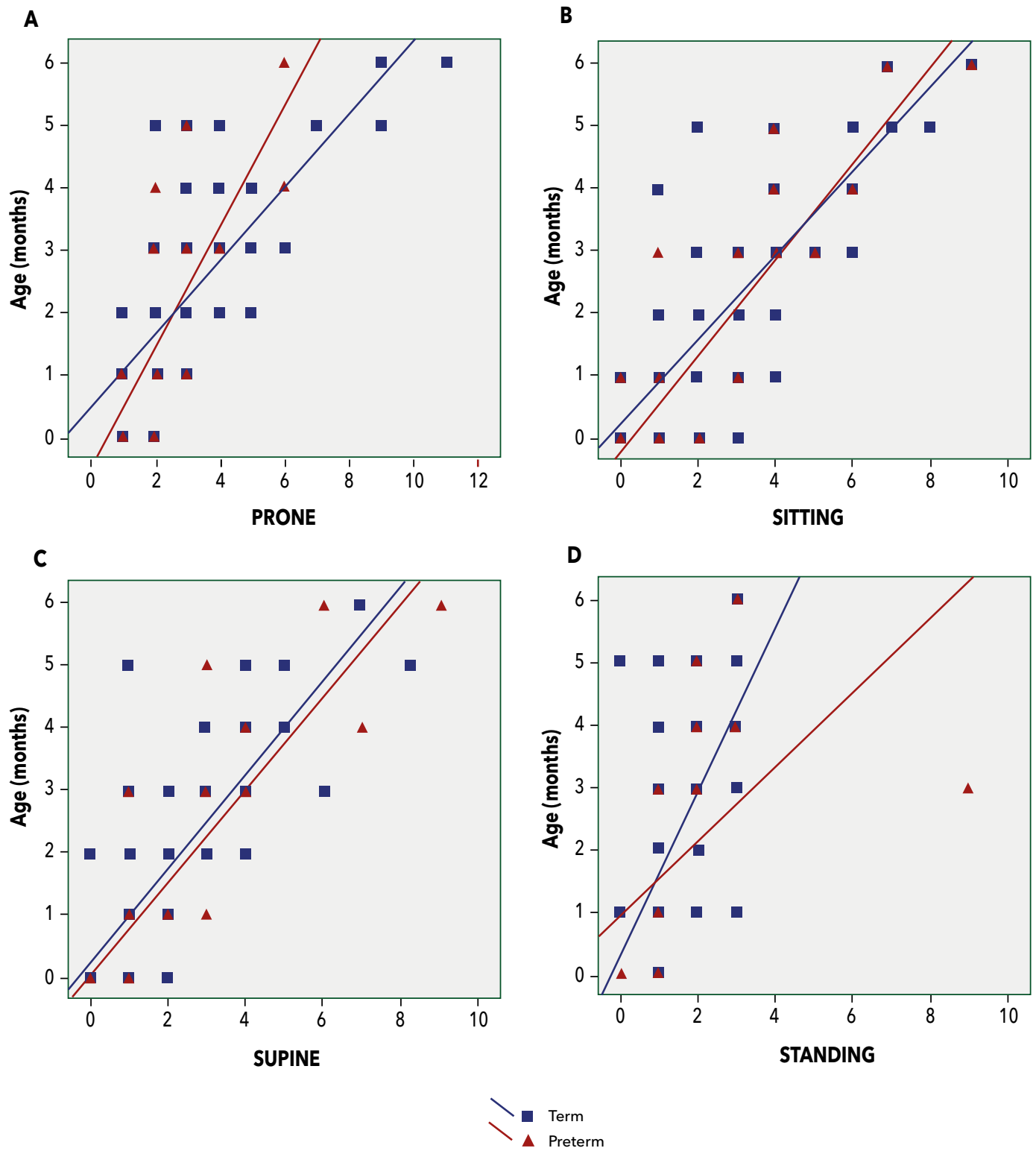

Figure 2 - Scatter diagram according to motor performance in Alberta Infant Motor Scale (AIMS) postures between preterm and term infants.

The supine posture (Figure 2C) showed similar behavior in both groups: premature infants were superior to term infants across the age groups; however, the acquisition of postures over the months was linear. Finally, regarding the standing posture (Figure 2D), it was observed that premature infants obtained better scores from 2 months of age; however, one premature infant scored much higher than the others. At the age of 3 months, preterm infants had lower scores than full-term infants.

\section{Discussion}

This study aimed to characterize the DM of infants assessed by a physical therapist during childcare consultations at the FHS and Child Care Center in the municipality of Uruguaiana, RS, in addition to discussing the importance of inserting a physical therapist in the primary health care team. The sample comprised 91 infants aged 0-6 months, a period in which mothers are most likely to visit the health unit. Through the AIMS 
categorization, it was possible to observe that most infants $(n=68)$ had a typical motor performance from $0-3$ months, and in this age group, there were nine premature infants, which corresponded to $29 \%$ of the sample. From 4-6 months, less than half (46.43\%) of the infants had a typical DM, and the percentage of premature infants in this age group was $38 \%$.

\section{Biological variables}

The municipality where this study was carried out had a prematurity rate of $11.25 \%$ in 2020 , according to data from the Information System on Live Births. ${ }^{15}$ These data are consistent with the actual situation in the country; approximately $1,722,907$ births took place in Brazil in 2020 , of which 202,843 were premature births, which is equivalent to $11.77 \%$. The World Health Organization reported that $5-18 \%$ of live births in 184 countries are premature. ${ }^{16}$ In the present study, the percentage of premature infants was $28.57 \%$.

Chiquetti et al. ${ }^{6}$ observed that the infants' motor performance was inversely proportional to prematurity; therefore, this condition is one of the risk factors for motor delay, an unfavorable outcome of DM. It is common to find in the literature that preterm infants are born with less weight and length, which is in line with the findings of this study since most of the infants in the sample had a weight and nutritional status adequate for their gestational age (87.91\%, 73\%, and 62\%, respectively). ${ }^{17}$ Of the 11 infants with low birth weight, 10 were premature; however, the length at birth and the head circumference of the babies in this study were within the expected range. 6,18

When we combine the factors of low birth weight and prematurity, we have a sum of risk factors for DM; the first predisposes to fewer motor skills and visualmotor integration, while the second is characterized by a reduction in muscle tone. ${ }^{6}$

\section{General motor development}

Considering that DM is sequential and continuous, it is expected that there is a positive correlation between postural control and the acquisition of new motor skills as age advances. However, the percentile values of children assessed in the first quarter of life were higher than those assessed in the second quarter of life. Some studies indicate that this may be a period of stability in some postures, in which infants change movement patterns in certain motor acquisitions. ${ }^{7,19}$ However, it is necessary to consider the sensitivity of the scale for extreme age groups. Some studies have already pointed out that AIMS has shown limitations regarding the representativeness of the items, low sensitivity to behavioral changes and less dispersion of the total scores in the first and sixth quarters. Thus, Saccani and Valentini ${ }^{14}$ suggest using other instruments to assess children in the first three months of life.

\section{Motor development-comparison between groups}

In the prone posture, premature infants had a higher score than infants in the first month of life. Although premature infants have difficulties in integrating and modulating stimuli immediately after birth, studies point out that they develop strategies to overcome the disadvantages inherent to their condition, promoting intense maturation, ${ }^{19}$ which is a period of adaptation to the stimuli resulting from early extrauterine life, which does not occur in full-term infants. ${ }^{20,21-23}$ This minor advantage of preterm infants does not last over time, as second-trimester infants have better motor performance, and longitudinal studies have observed that term infants have a greater variety of motor acquisitions and higher motor performance scores when compared with premature infants. ${ }^{18,22-24}$

Supine posture: In this study, term infants demonstrated better motor acquisition in the supine posture. Since the results were similar to those of other studies with a larger sample size, it is possible to base these findings on the difficulty in regulating axial muscle tone and deficient sensory processing typical of preterm infants. ${ }^{20,22}$ These characteristics can have a negative impact on the responses of postural control and the functions of the upper limbs, such as bringing the hands to the midline and reaching for and picking up objects. ${ }^{18,23,24}$

Standing posture: Children tend to have a lower score for this item at the beginning of the first year of life, which may result from the low environmental opportunities and few antigravity postures previously experienced, such as the prone posture, which will favor the formation of spinal curvature and provide opportunities for motor control while standing, factors that are essential for the maintenance of high posturess. ${ }^{18}$ Yet, full-term infants achieved important high acquisitions before preterm infants. 
Valentini et al. ${ }^{18}$ evaluated infants during the first 12 months of life and observed that the longest period of motor development for standing posture was between 6 and 12 months of age; however, a limitation of the present study is that we could not capture this progress owing to the inclusion of infants aged 0-6 months.

\section{Physical therapist performance}

The present study was carried out by a physical therapist of the collective health residency program, working at an FHS in the city, where she performed weekly multidisciplinary care during childcare consultations. Thus, it can be seen that to modify the motor scenario of children, it is important to identify early motor delays and deficits, so that intervention and early rehabilitation of possible developmental changes are carried out. ${ }^{12,25,26}$

This monitoring is more effective when performed by the primary care team, as this team is capable of intervening in the home and surrounding environment where the child lives, that is, acting on barriers and facilitators of child development. ${ }^{12,27,28}$ Studies show that they incorporate professionals who are not part of the primary FHS team and can increase the resolution of cases in primary care, supporting quality primary care. ${ }^{17}$

It is the responsibility of the physical therapist to study $\mathrm{DM}$, that is, a physical therapist is trained to act both in the assessment and intervention of disorders resulting from DM, in addition to focusing on functionality and independence, something that is sought in the evolution of a child so that in the future, he/she has autonomy in her care and better school performance.

A physical therapist working as a primary care professional, providing childcare, is responsible for guiding mothers, who are most often the main caregivers, about the DM expected for each stage of life, how to optimize its evolution, warning about the risks of prolonged use of prams and keeping the baby in the same position, the importance of interaction with the family and the environment, and the importance of sensorimotor stimulation. $9,10,27,28$ Since caregivers play a key role in promoting the child's health, they are the ones who will provide care and carry out the necessary guidelines for the growth and development of infants. ${ }^{26,28}$

\section{Conclusion}

The results of the present study show that infants evaluated in the first three months of life had better results in the AIMS categorization than older infants. As DM evolves, the difficulty of movements and demand for motor control increases; hence, children need to be challenged and given opportunities to favor DM. In the intergroup assessment, preterm infants showed a lower DM than full-term infants in most postures. This difference is more pronounced in older infants, which shows a slower evolution of DM in these infants and how prematurity represents a risk for motor delay.

Despite the evolution in academic training, physiotherapy still needs to break the paradigm of a purely rehabilitating profession and establish its duties in disease prevention and health promotion, in which it has much to contribute. For this, it is necessary to routinely insert physical therapists in primary care, which will increase the resolution of cases, avoid the overload of the secondary and tertiary sectors, and reduce waiting lists and costs for public health. In the present study, it was observed that the inclusion of a physical therapist in the care of children, together with a multidisciplinary team, can expand care and ensure a more specific and effective assessment of physical development, thereby establishing an early diagnosis of motor changes, since it is a question of a highly trained professional focused on movement and functionality.

\section{Authors' contributions}

KDPR planned the study, performed the data collection and analysis, and wrote the manuscript under the guidance of the other authors. AKZ assisted with planning the study, guided the field data collection and part of the laboratory analyses, and assisted with data analysis and writing the manuscript. EMSC assisted with planning the study, guided the field data collection and part of the laboratory analyses, and assisted with the data analysis and writing the manuscript.

\section{References}

1. Brasil. Ministério da Saúde, Secretaria de Vigilância em Saúde, Secretaria de Atenção à Saúde. Política Nacional de Promoção da Saúde. 3rd ed. Brasília : Ministério da Saúde; 2010. Full text link

2. Brigida ECSS, Sousa SAC. O papel da puericultura na saúde da criança. J Specialist. 2018;1(2):1-15. Full text link

3. Schmitt LR, Corrêa BP, Nunes IM, Mariot MDM, Silva CH. A puericultura no primeiro ano de vida - uma avaliação na atenção primária em saúde. Rev Rede Cuid Saude. 2020;14(2):12-28. Full text link 
4. Gallahue DL, Ozmun JC, Goodway JD. Compreendendo o desenvolvimento motor: bebês, crianças, adolescentes e adultos. 7 ed. Porto Alegre: AMGH; 2013. 488 p.

5. Saccani R, Valentini NC, Pereira KR, Müller AB, Gabbard C. Associations of biological factors and affordances in the home with infant motor development. Pediatr Int. 2013;55(2):197-203. DOI

6. Chiquetti EMS, Carvalho ACF, Zanella AK, Valentini NC. Fatores de risco e desenvolvimento motor de bebês pequenos para idade gestacional (PIG) a termo e pré-termo. Rev Varia Sci Cienc Saude. 2018;4(1):110-8. Full text link

7. Pereira KRG, Saccani R, Valentini NC. Cognição e ambiente são preditores do desenvolvimento motor de bebês ao longo do tempo. Fisioter Pesqui. 2016;23(1):59-67. DOI

8. Panceri C, Pereira KRG, Valentini NC. A intervenção motora como fator de prevenção de atrasos no desenvolvimento motor e cognitivo de bebês durante o período de internação hospitalar. Cad Bras Ter Ocup. 2017;25(3):469-79. DOI

9. Ferreira OGL, Castro TTS, Santiago SF, Meló SFP, Melo ELA, Araújo VS. A presença do fisioterapeuta na puericultura no olhar dos profissionais de uma unidade de saúde da família. Saude (Santa Maria). 2015;41(2):63-70. DOI

10. Blascovi-Assis S, Vianna DL, Peixoto BO. Reflexões sobre o crescimento da fisioterapia e sua contribuição para a área dos distúrbios do desenvolvimento. Cad Pós-Grad Disturb Desenvolv. 2010;10(1):32-6.

11. Sá MBN, Costa MTF. A atuação do fisioterapeuta no acompanhamento do desenvolvimento infantil na Atenção Primária. Rev Digital Simonsen. 2020;12:35-49. Full text link

12. Freire LPV, Sales WB, Barbosa DS, Morais JD. As atribuições do fisioterapeuta do Núcleo Ampliado a Saúde da Família e Atenção Básica no município de Lucena-PB. Arch Health Invest. 2020;9(1):67-73. DOI

13. Valentini NC, Saccani R. Brazilian validation of the Alberta Infant Motor Scale. Phys Ther. 2012;92(3):440-7. DOI

14. Saccani R, Valentini NC. Análise do desenvolvimento motor de crianças de zero a 18 meses de idade: representatividade dos itens da Alberta Infant Motor Scale por faixa etária e postura.
Rev Bras Crescimento Desenvolv Hum. 2010;20(3):711-22. Full text link

15. Brasil. Ministério da Saúde. Secretaria de Vigilância em Saúde. Painel de Monitoramento de Nascidos Vivos. 2020 [cited 2020 Feb 23]. Available from: https://tinyurl.com/32k6tabv

16. Nishioka SA. Confinamento pela pandemia de COVID-19 e diminuição acentuada da taxa de partos prematuros. 2020 [cited 2020 Feb 23]. Available from: https://tinyurl.com/e8usjnny

17. Rabello MSC, Barros SMO. Aspectos clínicos e epidemiológicos da prematuridade em um centro de parto normal, São Paulo, Brasil. Einstein. 2011;9(4 Pt 1):483-8. DOI

18. Valentini NC, Pereira KRG, Chiquetti EMS, Formiga CKMR, Linhares MBM. Motor trajectories of preterm and full-term infants in the first year of life. Pediatr Int. 2019;61(10):967-77. DOI

19. Darrah J, Hodge M, Magill-Evans J, Kembhavi G. Stability of serial assessments of motor and communication abilities in typically developing infants - implications for screening. Early Hum Dev. 2003;72(2):97-110. DOI

20. Raniero EP, Tudella E, Mattos RS. Padrão e ritmo de aquisição das habilidades motoras de lactentes pré-termo nos quatro primeiros meses de idade corrigida. Rev Bras Fisioter. 2010;14(5):396-403. DOI

21. Piper MC, Byrne PJ, Darrah J, Watt MJ. Gross and fine motor development of preterm infants at eight and 12 months of age. Dev Med Child Neurol. 1989; 31(5):591-7. DOI

22. Cabral TI, Silva LGP, Martinez CMS, Tudella E. Analysis of sensory processing in preterm infants. Early Hum Dev. 2016; 103:77-81. DOI

23. Leone CR, Ramos JLA, Vaz FAC. O recém-nascido pré-termo. In: Marcondes E, Vaz FAC, Ramos JLA, Okay Y. Pediatria básica. 9th ed. São Paulo: Sarvier; 2002. p. 348-52.

24. Saccani R, Valentini NC, Pereira KRG. New Brazilian developmental curves and reference values for the Alberta infant motor scale. Infant Behav Dev. 2016;45(Pt A):38-46. DOI

25. Souza KC, Bertolini DA. Importância do fisioterapeuta na atenção primária à saúde e a realidade de um município do norte do Paraná. Rev Uninga. 2019;56(S4):182-96. Full text link 
26. Damasceno SS, Nóbrega VM, Coutinho SED, Reichert APS, Toso BRGO, Collet N. Saúde da criança no Brasil: orientação da rede básica à Atenção Primária à Saúde. Cienc Saude Colet. 2016;21(9):2961-73. DOI

27. Madaschi V, Paula CS. Medidas de avaliação do desenvolvimento infantil: uma revisão da literatura nos últimos cinco anos. Cad Pós-Grad Disturb Desenvolv. 2011;11(1):52-6. Full text link

28. Oliveira EAR, Rocha SS. O cuidado cultural dos pais na promoção do desenvolvimento infantil. R Pesq Cuid Fundam Online. 2019;11(2):397-403. DOI 